\title{
RANGE EXPANSION OF AN INVASIVE PUFFERFISH, LAGOCEPHALUS SCELERATUS (ACTINOPTERYGII: TETRAODONTIFORMES: TETRAODONTIDAE), TO THE SOUTH-WESTERN MEDITERRANEAN
}

\author{
M. Hichem KARA ${ }^{1 *}$, Emna BEN LAMINE ${ }^{2,3}$, and Patrice FRANCOUR ${ }^{3}$ \\ ${ }^{1}$ Marine Bioresources Laboratory, Annaba University Badji Mokhtar, Annaba, Algeria \\ ${ }^{2}$ Institut National Agronomique de Tunisie, Unité de recherche Écosystèmes \& Ressources \\ Aquatiques, Tunis, Tunisia \\ ${ }^{3}$ University of Nice Sophia Antipolis, ECOMERS Laboratory, Faculty of Sciences, Nice Cedex, France
}

\begin{abstract}
Kara M.H., Ben Lamine E., Francour P. 2015. Range expansion of an invasive pufferfish, Lagocephalus sceleratus (Actinopterygii: Tetraodontiformes: Tetraodontidae), to the south-western Mediterranean. Acta Ichthyol. Piscat. 45 (1): 103-108.
\end{abstract}

\begin{abstract}
Three specimens of silver-cheeked toadfish, Lagocephalus sceleratus (Gmelin, 1789), were caught on eastern coasts of Algeria during the winter of 2013-2014. This is the first record of this invasive species from Algeria, providing further evidence of its occurrence along north-African coasts and confirming its entry into the Western basin of the Mediterranean. The human-health implications of this toxic fish in this region are discussed.
\end{abstract}

Keywords: fish, Lessepsian migrant, silver-cheeked toadfish, giant toadfish, silverside blaasop, spotted roughbacked blowfish, alien, non-indigenous species, Algeria

Representatives of the family Tetraodontidae are marine and estuarine fishes distributed in tropical and subtropical areas of the Atlantic-, Indian-, and Pacific Oceans. This family comprises 26 genera and 189 species (Froese and Pauly 2014), among which nine can be found in the Mediterranean (Akyol et al. 2005, Corsini et al. 2005, Golani et al. 2006), of which seven are non-indigenous (Golani et al. 2002).

The genus Lagocephalus is distinguished from other genera of Tetraodontidae by two separate lateral lines, the lower usually on a fold of skin, a caudal peduncle rather narrow, a lunate caudal fin, two nostrils on each side of the snout with more or less developed papilla, and no bony plates on the back. This genus includes four species inhabiting the Mediterranean. Only Lagocephalus lagocephalus (Linnaeus, 1758) is of Atlanto-Mediterranean origin, while the remaining three species: Lagocephalus spadiceus (Richardson, 1845); Lagocephalus suezensis Clark et Gohar, 1953; and Lagocephalus sceleratus (Gmelin, 1789) are Lessepsian migrants, which have penetrated to the Levantine basin by way of the Suez Canal. Lagocephalus sceleratus can be distinguished from all its Mediterranean congeners by the following characters: the regular distribution of spots of equal size along the dorsal area, the absence of spiny rays in the dorsal and anal fins, and the presence of small spinules on the belly and on the dorsal surface extending to the origin of the dorsal fin.

The silver-cheeked toadfish, Lagocephalus sceleratus (known also as giant toadfish, silverside blaasop, or spotted rough-backed blowfish), is a reef-associated species, widely distributed in the tropical Indo-West Pacific Ocean (Smith and Heemstra 1986) as well as the Red Sea, and more recently in the eastern basin of the Mediterranean Sea. Its first record was published by Filiz and Er (2004) and it documented a finding from Gökova Bay (southern Aegean Sea, Turkey). The chronologically first observed specimen, however, was captured in 2003, but reported later by Akyol et al. (2005). The previous 1977 record by Mouneimne (1977) was a misidentification of the similar puffer fish Lagocephalus suezensis (see Golani 1996). Soon after its first detection, the species underwent a population explosion in many localities of the Levant Basin such as Israel (Golani and Levy 2005), Turkey (Bilecenoglu et al. 2006), Crete (Kasapidis et al. 2007), and Cyprus (Katsanevakis et al. 2009). In 2011, Halim and Rizkalla (2011) provided concrete evidence of the occurrence of $L$. sceleratus along the Mediterranean coast of Egypt and considered that this species was first caught in 2008 off Alexandria, becoming abundant soon afterwards, especially along the coasts of the Sinai and off the Nile

\footnotetext{
${ }^{*}$ Correspondence: Pr. M. Hichem Kara, Laboratoire Bioressources Marines, Université d'Annaba Badji Mokhtar, Annaba, Algérie, phone: +213 770312458, fax: +213 38868510, e-mail: (MHK) kara_hichem@yahoo.com, (EB) emna.ben-lamine@unice.fr, (PF) patrice.francour@unice.fr.
} 
Delta. It has since then showed a rapid expansion throughout the eastern Mediterranean Sea reaching its northernmost parts: Ionian Sea (Kapiris et al. 2014) and mid-eastern Adriatic (Dulčić et al. 2014), Libya (Milazzo et al. 2012), as well as south-western- (Jribi and Bradai 2012) and northern Tunisia (Ben Souissi et al. 2014). Table 1 summarizes the chronology of documented records (location of capture, date, number and length of the specimens, depth) of this species in the Mediterranean.

The silver-cheeked toadfish, Lagocephalus sceleratus, is one of the largest members of its family, reaching $110 \mathrm{~cm}$ of total length and $7 \mathrm{~kg}$ of weight (Nader et al. 2012). Generally, it inhabits sandy or muddy substrate areas near shallow coral reefs at depths between 18 and $100 \mathrm{~m}$ (Smith and Heemstra 1986, Froese and Pauly 2014). In eastern Mediterranean (Rhodes), according to Kalogirou (2013), this species was found to feed on invertebrates and fish. During the early life stages, it feeds on various invertebrates. The predominant mollusc species found in the diet of the larger $(>20 \mathrm{~cm})$ L. sceleratus individuals were the economically important Sepia officinalis and Octopus vulgaris. The size at which $50 \%$ of individuals are mature was estimated at $36 \mathrm{~cm}$ (Kalogirou 2013).

In this paper, we present the first record of the silvercheeked toadfish, Lagocephalus sceleratus, in Algerian waters, confirming the spreading of this invasive species in the western Mediterranean, and discussing the risks it poses to the health of consumers who are in general unaware of its toxicity.

During the winter of 2013-2014, three specimens of Lagocephalus sceleratus were caught on the eastern coast of Algeria (Fig. 1) using bottom trawl and gillnet to a depth of 50 to $60 \mathrm{~m}$. Field constraints did not allow preservation of these individuals which were identified on

Table 1

Chronology of documented records of Lagocephalus sceleratus in the Mediterranean

\begin{tabular}{|c|c|c|c|c|c|c|}
\hline No. & Location & Date & $N$ & $\begin{array}{l}\text { Total length } \\
{[\mathrm{cm}]}\end{array}$ & $\begin{array}{l}\text { Depth } \\
{[\mathrm{m}]}\end{array}$ & Reference \\
\hline 1 & Akyaka (Gökova Bay), Turkey & 08.2003 & 1 & - & - & Filiz and Er 2004 \\
\hline 2 & Kemer (Antalya Bay), Turkey & 18.09.2004 & 1 & 38.9 & 30 & Bilecenoglu et al. 2006 \\
\hline 3 & Jaffa coast, Israel & 08.11 .2004 & 1 & 10.1 & - & Golani and Levy 2005 \\
\hline 4 & Cyprus & 2004 & several & - & - & Katsavenakis et al. 2009 \\
\hline 5 & Haifa Bay, Israel & 24.02.2005 & 1 & 61.8 & 30 & Golani and Levy 2005 \\
\hline 6 & Bodrum (Gokova Bay), Turkey & 10.03 .2005 & 2 & - & - & Bilecenoglu et al. 2006 \\
\hline 7 & Adrasan coast (Antalya Bay), Turkey & 14.03.2005 & 2 & - & 3 & Bilecenoglu et al. 2006 \\
\hline 8 & Crete (Heraklion Bay), Greece & 20.07 .2005 & 1 & 34.8 & 9 & Kasapidis et al., 2007 \\
\hline 9 & Rhodes coast (Ladiko), Greece & 21.09 .2005 & 1 & 37.6 & $15-20$ & Corsini et al. 2006 \\
\hline 10 & Kas (Antalya Bay), Turkey & 03.10 .2005 & 1 & - & - & Bilecenoglu et al. 2006 \\
\hline 11 & Chania (Georgioupolis Bay), Greece & 20.12.2005 & 1 & - & 30 & Kasapidis et al. 2007 \\
\hline 12 & Hekim island (Izmir Bay), Turkey & 21.04.2006 & 1 & 49.8 & $10-12$ & Bilecenoglu et al. 2006 \\
\hline 13 & Behramkale (Edremit Bay), Turkey & 07.2008 & 1 & - & 60 & Türker-Çakır et al. 2009 \\
\hline 14 & Alexandria, Egypt & 2008 & several & - & 80 & Halim and Rizkalla 2011 \\
\hline 15 & Rhodes island, Greece & $2008 / 2009$ & 290 & $5.3-63.1$ & $5-35$ & Kalogirou 2013 \\
\hline 16 & Iskenderun Bay, Turkey & 02.2009 & 4 & $38.8-61.1$ & 40 & Torcu Koç et al. 2011 \\
\hline 17 & Antalya Bay, Turkey & $2008 / 2010$ & 656 & $12.5-65$ & - & Aydin 2011 \\
\hline 18 & Ain Al Ghazala lagoon, Libya & 09.2010 & 5 & 27.8 & $15-25$ & Milazzo et al. 2012 \\
\hline 19 & Mersin Bay, Turkey & 10.11.2010 & 2 & $8.4,7.5$ & 72 & Yaglioglu et al. 2011 \\
\hline 20 & Iskenderun Bay, Turkey & 29.11.2010 & 2 & $7.5,6.5$ & 53 & Yaglioglu et al. 2011 \\
\hline 21 & Gulf of Gabes, Tunisia & 08.12 .2010 & 1 & 60 & - & Jribi and Bradai 2012 \\
\hline 22 & Tunisian coasts & $12.2010-07.2013$ & 12 & $52-64$ & - & Ben Souissi et al. 2014 \\
\hline 23 & Iskenderun Bay, Turkey & $2011 / 2012$ & 77 & $8.9-78.4$ & $8-50$ & Başusta et al. 2013 \\
\hline 24 & Jakljan island (mid-E Adriatic), Croatia & 17.10 .2012 & 1 & 66.3 & - & Sulić Šprem et al. 2014 \\
\hline 25 & Trebinje (Middle eastern Adriatic), Croatia & 17.03 .2013 & 1 & 49.2 & - & Dulčić et al. 2014 \\
\hline 26 & Lampedusa Island, Italy & 07.10 .2013 & 1 & 41 & 20 & Azzurro et al. 2014 \\
\hline 27 & Avola (South eastern Ionian Sea), Italy & 16.01 .2014 & 1 & 65 & $15-20$ & Kapiris et al. 2014 \\
\hline 28 & El Kala, Algeria & 14.12.2013 & 1 & - & - & This study \\
\hline 29 & Annaba, Algeria & 11.01 .2014 & 2 & $32-48$ & $50-60$ & This study \\
\hline
\end{tabular}

$N=$ number of specimens studied. 
the basis of photographs and according to the observations made on the site of capture. These photographs allowed clear recognition of important taxonomic characters which are in agreement with the descriptions of Smith and Heemstra (1986) and Turan (2007).

Data on the three catches are given in Table 2. The body of the captured specimens was elongated and cylindrical, slightly compressed laterally and ventrally (Fig. 2). Back and upper flanks silvery to grey covered with black dots. The belly was white and rough. The dorsal and anal fins were short-based and posterior in position. These specimens are also characterized by: the absence of body scales, two quite distinct lateral lines, gill opening of a single slit in front of the pectoral fins, pectoral fins with a wide base and a round posterior edge, top of the pectoral fin base below the lower margin of the eye, a distinct wide silver band on the lower part of the flanks and a silver blotch in front of the eyes, dark pectoral fin base and white belly, grey-brownish dorsal area with black, regularly distributed spots of equal size.

Lagocephalus sceleratus was thought to be absent from the entire African Mediterranean coast (Shakman and Kinzelbach 2007), although its presence was suspect- ed by Golani (2010). Our observations provided additional evidence - after Jribi and Bradai (2012), Milazzo et al. (2012), and Ben Souissi et al. (2014) — of the occurrence of L. sceleratus along the North African coast and its spread in the Western Mediterranean. The relatively large size of individuals captured and their presence in the Far East of Algerian coast suggests their arrival from their last place of record on the north-western coast of Tunisia, near Tabarka (Ben Souissi et al. 2014). Among specimens collected in Tunisia, some females were mature with ripe gonads (gonad weight up to $245 \mathrm{~g}$ ), suggesting that a breeding population may be established.

Lagocephalus sceleratus is the sixth non indigenous teleost fish species recorded in Algeria, after the Senegalese sole, Solea senegalensis Kaup, 1858 (see Chaoui and Kara 2004); the Bermuda sea chub, Kyphosus sectator (Linnaeus, 1758) (see Hemida et al. 2004); the blue-spotted cornetfish, Fistularia commersonii Rüppell, 1838 (see Kara and Oudjane 2009); the spotted halfbeak, Hemiramphus far (Forsskål, 1775) (see Kara et al. 2012); and the blackmouth splitfin, Synagrops japonicus (Döderlein, 1883) (see Hannachi et al. in press*). It is the second representative of Tetraodontidae found after the

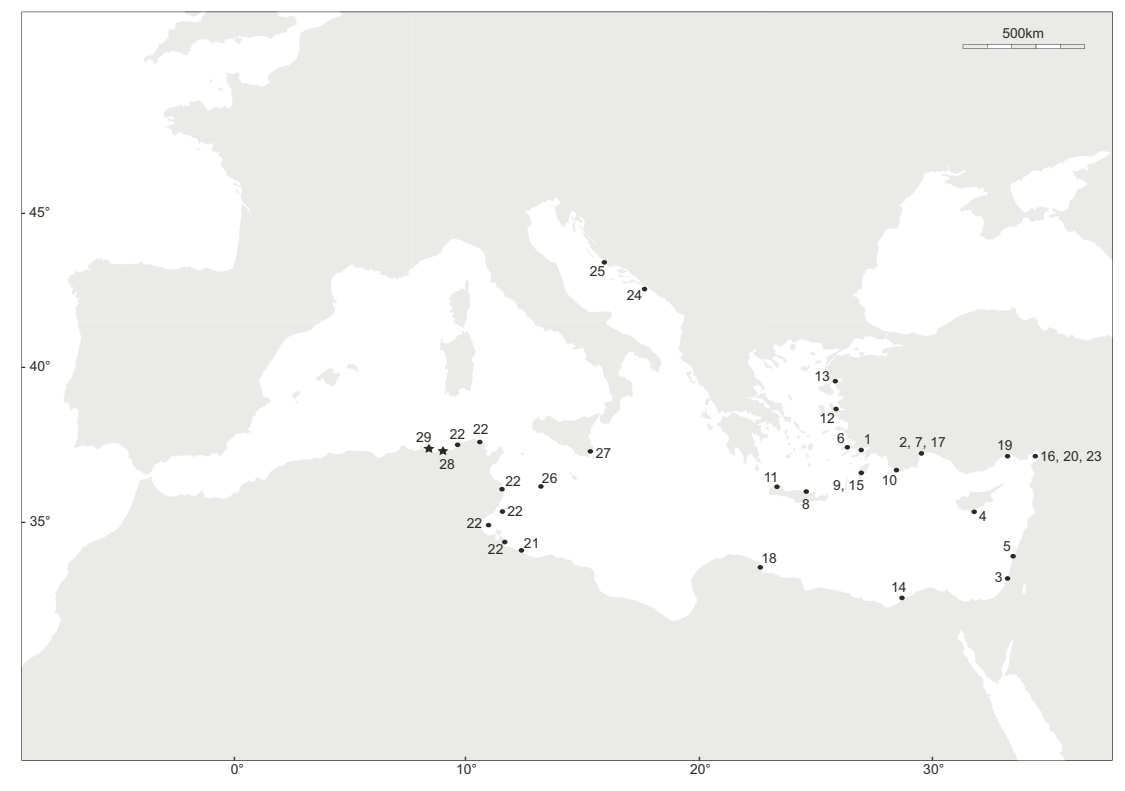

Fig. 1. Map pointing out the capture area of Lagocephalus sceleratus on Algerian coasts (stars) and chronology of the first records in the Mediterranean; Record numbers explained in Table 1

Table 2

Characteristics of catches of Lagocephalus sceleratus carried out on the Eastern coast of Algeria

\begin{tabular}{lccccccc}
\hline No. & Locality & Geographic coordinates & Date & $\begin{array}{c}\text { Depth } \\
{[\mathrm{m}]}\end{array}$ & $\begin{array}{c}\text { TL } \\
{[\mathrm{cm}]}\end{array}$ & $\begin{array}{c}W_{\mathrm{t}} \\
{[\mathrm{g}]}\end{array}$ & Fishing gear \\
\hline 1 & El Kala & $36^{\circ} 56^{\prime} 16^{\prime \prime} \mathrm{N}, 8^{\circ} 27^{\prime} 21^{\prime \prime} \mathrm{E}$ & $14 / 12 / 2013$ & - & - & - & Gillnet \\
2 & Annaba & $36^{\circ} 54^{\prime} 22^{\prime \prime} \mathrm{N}, 7^{\circ} 54^{\prime} 38^{\prime \prime} \mathrm{E}$ & $11 / 01 / 2014$ & 60 & 48 & 1400 & Trawl \\
3 & Annaba & $36^{\circ} 54^{\prime} 30^{\prime \prime} \mathrm{N}, 7^{\circ} 48^{\prime} 12^{\prime \prime} \mathrm{E}$ & $11 / 01 / 2014$ & 50 & 32 & 788 & Trawl \\
\hline
\end{tabular}

$\mathrm{TL}=$ total length, $W_{\mathrm{t}}=$ total weight.

\footnotetext{
${ }^{*}$ Hannachi M.S., Boubekeur M.S., Derbal F., Kara M.H. 2015(?) Unusual presence of juveniles of the Indo-Pacific blackmouth splitfin Synagrops japonicus in the southwest Mediterranean coast. Acta Adriatica, in press.
} 


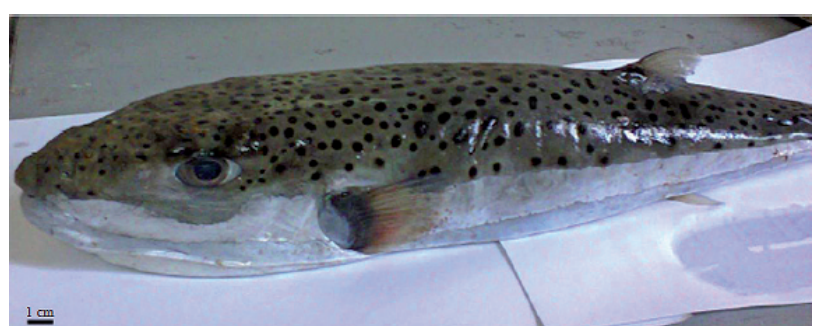

Fig. 2. Specimen of Lagocephalus sceleratus (No. 02 from Table 2; $48 \mathrm{~cm}$ TL) captured in Annaba on 11 January 2014

blunthead puffer, Sphoeroides pachygaster (Müller et Troschel, 1848) (see Hemida et al. 2009). The observed increase of the mean annual temperature observed within the last several years in the Mediterranean waters (Béthoux et al. 1990, Francour et al. 1994, Vargas-Yáñez et al. 2005) could possibly explain the recent spreading of Lessepsian migrants from the eastern to the western Mediterranean basin, and their progressive geographical dispersal (Koukouras et al. 2010). In addition to the presently observed warming of the western basin, the changes in the main current circulation in the Mediterranean during the last few decades may also explain the recent spread of Red Sea species towards the western basin (see Francour et al. 2010, Otero et al. 2013). To reach the Algerian coast, L. sceleratus moved from East to West against the general current circulation along the North African coast. However, its spreading to the north-western basin, especially along the Italian and French coasts will be favoured by the Ligurian Current and we can then predict its subsequent spreading northward.

Lagocephalus sceleratus has already established a population, which is colonizing new territories of the eastern Mediterranean at a relatively rapid rate. Today, it is regarded to be among the most successful invasive species in the Mediterranean Sea with a significant impact on the surrounding ecosystem and on the fisheries sector (Zenetos et al. 2005, Peristeraki et al. 2006, Streftaris and Zenetos 2006). Kalogirou (2013) classified this species as a pest for fisheries and a potential threat for biodiversity, and L. sceleratus has been included in the black list of the 18 worst fish species by the IUCN (Otero et al. 2013). More importantly, L. sceleratus is considered to be a serious hazard to consumers since it contains a strong marine toxin called tetrodotoxin (TTX), which can be lethal to humans (Kasapidis et al. 2007, Bentur et al. 2008, Eisenman et al. 2008, Katikou et al. 2009). TXT is a nonprotein organic compound (aminoperhydroquinazoline) and one of the strongest marine paralytic toxins known today (El-Ganainy et al. 2006). Up to now, three cases of poisoning of persons who had consumed this fish were reported from Israel, Lebanon (Golani et al. 2006), and Tunisia (Ben Souissi et al. 2014). In Egypt, although landing of these fishes is forbidden as a commercial species, they are illegally landed and consumed as food in the Red Sea and Gulf of Suez areas. It is considered delicious seafood in Suez City, Egypt, where it is illegally sold, decapitated and eviscerated (Halim and Rizkalla 2011) in spite of several fatal poisonings being reported there (Zaki 2004). Thus, the dramatic spread of the species along the Mediterranean coast reinforces the need for a public information campaign, especially in North African countries, to raise awareness of the dangers to human health (Azzurro 2010). To implement such an information campaign, a previous clear information workflow from scientists to public authorities and policy makers should be established.

\section{REFERENCES}

Akyol O., Ünal V., Ceyhan T., Bilecenoglu M. 2005. First confirmed record of Lagocephalus sceleratus (Gmelin, $1789)$ in the Mediterranean Sea. Journal of Fish Biology 66 (4): 1183-1186.

DOI: $10.1111 / \mathrm{j} .0022-1112.2005 .00667 . \mathrm{x}$

Aydın M. 2011. Growth, reproduction and diet of pufferfish (Lagocephalus sceleratus Gmelin, 1789) from Turkey's Mediterranean Sea coast. Turkish Journal of Fisheries and Aquatic Sciences 11 (4): 569-576.

DOI: $10.4194 / 1303-2712-v 11 \_4 \_10$

Azzurro E. 2010. Unusual occurrences of fish in the Mediterranean Sea: An insight on early detection. Pp. 99-126. In: Golani D., Appelbaum-Golani B. (eds.) Fish invasions of the Mediterranean Sea: Change and renewal. Pensoft Publishers, Sofia-Moscow.

Azzurro E., Castriota L., Falautano M., Giardina F., Andaloro F. 2014. The silver-cheeked toadfish Lagocephalus sceleratus (Gmelin, 1789) reaches Italian waters. Journal of Applied Ichthyology 30 (5) 1050-1052. DOI: 10.1111 /jai.12471

Başusta A., Başusta N., Özer E.I. 2013. Length-Weight relationship of two puffer fishes, Lagocephalus sceleratus and Lagocephalus spadiceus, from Iskenderun Bay, northeastern Mediterranean, Turkey. Pakistan Journal of Zoology 45 (4): 1047-1051.

Ben Souissi J., Rifi M., Ghanem R., Ghozzi L., Boughedir W., Azzurro E. 2014. Lagocephalus sceleratus (Gmelin, 1789) expands through the African coasts towards the Western Mediterranean Sea: a call for awareness. Management of Biological Invasions 5 (4): 357-362.

DOI: $10.3391 / \mathrm{mbi} .2014 .5 .4 .06$

Bentur Y., Ashkar J., Lurie Y., Levy Y., Azam Z.S., Litmanovich M., Golik M., Gurevych B., Golani D., Eisenman A. 2008. Lessepsian migration and tetrodotoxin poisoning due to Lagocephalus sceleratus in the eastern Mediterranean. Toxicon 52 (8): 964-968.

DOI: $10.1016 /$ j.toxicon.2008.10.001

Béthoux J.P., Gentili B., Raunet J., Tailliez D. 1990. Warming trend in the Western Mediterranean deep water. Nature 347 (6294): 660-662.

DOI: $10.1038 / 347660 \mathrm{a} 0$

Bilecenoglu M., Kaya M., Akalin S. 2006. Range expansion of silverstripe blaasop, Lagocephalus sceleratus (Gmelin, 1789), to the northern Aegean Sea. Aquatic Invasions 1 (4): 289-291. DOI: 10.3391/ai.2006.1.4.14

Chaoui L., Kara M.H. 2004. Premier signalement de la sole du Sénégal Solea senegalensis (Soleidae) dans la lagune du Mellah (Algérie nord-est). Cybium 28 (3): 267-268. 
Corsini M., Margies P., Kondilatos G., Economidis P.S. 2005. Lessepsian migration of fishes to the Aegean Sea: First record of Tylerius spinosissimus (Tetraodontidae) from the Mediterranean, and six more fish records from Rhodes. Cybium 29 (4): 347-354.

Corsini M., Margies P., Kondilatos G., Economidis P.S. 2006. Three new exotic fish records from the SE Aegean Greek waters. Scientia Marina 70 (2): 319-323. DOI: $10.3989 /$ scimar.2006.70n2319

Dulčić J., Dragičević B., Antolović N., Sulić-Šprem J., Kožul V., Grgičević R. 2014. Additional records of Lobotes surinamensis, Caranx crysos, Enchelycore anatina, and Lagocephalus sceleratus (Actinopterygii) in the Adriatic Sea. Acta Ichthyologica et Piscatoria 44 (1): 71-74. DOI: 10.3750/AIP2014.44.1.09

Eisenman A., Rusetski V., Sharivker D., Yona Z., Golani D. 2008. An odd pilgrim in the Holy Land. American Journal of Emergency Medicine 26 (3): 383.e3-383.e6 DOI: 10.1016/j.ajem.2007.05.035

El-Ganainy A.A., Sabrah M.M., Zaky M.A. 2006. Biology and toxicity of the pufferfish Lagocephalus sceleratus (Gmelin, 1789) from the Gulf of Suez. Egyptian Journal of Aquatic Research 32: 283-297.

Filiz H., Er M. 2004. Akdenizin yeni misafiri. [New guests in the Mediterranean Sea.] Deniz Magazin 68: 52-54. [In Turkish.]

Francour P., Boudouresque C.F., Harmelin J.G., HarmelinVivien M., Quignard J.P. 1994. Are the Mediterranean waters becoming warmer? Information from biological indicators. Marine Pollution Bulletin 28 (9): 523-526. DOI: $10.1016 / 0025-326 \mathrm{X}(94) 90071-\mathrm{X}$

Francour P., Mangialajo L., Pastor J. 2010. Mediterranean marine protected areas and non-indigenous fish spreading. Pp. 127-144. In: Golani D., Appelbaum-Golani B. (eds.) Fish invasions of the Mediterranean Sea: Change and renewal. Pensoft Publisher, Sofia-Moscow.

Froese R., Pauly D. (eds.) 2014. FishBase. [version 07/2014] http://www.fishbase.org.

Golani D. 1996. The marine ichthyofauna of the eastern Levant-history, inventory and characterization. Israel Journal of Zoology 42 (1): 15-55. DOI: $10.1080 / 00212210.1996 .10688830$

Golani D. 2010. Colonization of the Mediterranean by Red Seafishes via the Suez Canal-Lessepsian migration. Pp. 145-188. In: Golani D., Appelbaum-Golani B. (eds.) Fish invasions of the Mediterranean Sea: Change and renewal. Pensoft Publishers, Sofia-Moscow.

Golani D., Levy Y. 2005. New records and rare occurrences of fish species from the Mediterranean coast of Israel. Zoology in the Middle East 36 (1): 27-32.

DOI: $10.1080 / 09397140.2005 .10638124$

Golani D., Orsi-Relini L., Massutí E., Quignard J.P. 2002. CIESM Atlas of exotic species in the Mediterranean. CIESM Publishers, Monaco.

Golani D., Öztürk B., Başusta N. 2006. Fishes of the eastern Mediterranean. Turkish Marine Research Foundation, Istanbul, Turkey.

Halim Y., Rizkalla S. 2011. Aliens in Egyptian Mediterranean waters. A check-list of Erythrean fish with new records.
Mediterranean Marine Science 12 (2): 479-490.

DOI: $10.12681 / \mathrm{mms} .46$

Hemida F., Ben Amor M.M., Capapé C. 2009. First confirmed record of the blunthead puffer, Sphoeroides pachygaster (Osteichthyes: Tetraodontidae) off the Algerian coast (south-western Mediterranean). Pan-American Journal of Aquatic Sciences 4 (2): 188-192.

Hemida F., Kanoun N., Golani D., Ben Souissi J., Guélorget O., Capapé C. 2004. Records of the Bermuda sea chub, Kyphosus sectator (Linnaeus, 1758) (Osteichthyes: Kyphosidae) from the coastal waters of Algeria (southern Mediterranean). Annales. Series Historia Naturalis 14 (1): 49-52.

Jribi I., Bradai M.N. 2012. First record of the Lessepsian migrant species Lagocephalus sceleratus (Gmelin, 1789) (Actinopterygii: Tetraodontidae) in the Central Mediterranean. Bioinvasions Records 1 (1): 49-52.

DOI: 10.3391/bir.2012.1.1.11

Kalogirou S. 2013. Ecological characteristics of the invasive pufferfish Lagocephalus sceleratus (Gmelin, 1789) in Rhodes, eastern Mediterranean Sea. A case study. Mediterranean Marine Science 14 (2): 251-260.

DOI: $10.12681 / \mathrm{mms} .364$

Kapiris K., Apostolidis C., Baldacconi R., Başusta N., Bilecenoglu M., Bitar G., Bobori D.C., Boyaci Y.Ö., Dimitriadis C., Djurović M., Dulčić J., Durucan F., Gerovasileiou V., Gökoğlu M., Koutsoubas D., Lefkaditou E., Lipej L., Marković O., Mavrič B., Özvarol Y., Pesic V., Petriki O., Siapatis A., Sini M., Tibullo D., Tiralongo F. 2014. New Mediterranean marine biodiversity records (April, 2014). Mediterranean Marine Science 15 (1): 198-212.

DOI: $10.12681 / \mathrm{mms} .737$

Kara M.H., Oudjane F. 2009. First observations of the IndoPacific bluespotted cornetfish Fistularia commersonii (Fistulariidae) from Algerian coasts. Marine Biodiversity Records 2: e83. DOI: 10.1017/S1755267209000438

Kara M.H., Rouag F., Laouira L. 2012. Westward range expansion of the Lessepsian spotted halfbeak Hemiramphus far (Hemiramphidae) in the Mediterranean Sea. Marine Biodiversity Records 5: e45. DOI: $10.1017 /$ S1755267212000139

Kasapidis P., Peristeraki P., Tserpes G., Magoulas A. 2007. First record of the Lessepsian migrant Lagocephalus sceleratus (Gmelin 1789), (Osteichthyes: Tetraodontidae) in the Cretan Sea (Aegean, Greece). Aquatic Invasions 2 (1): 71-73. DOI: 10.3391/ai.2007.2.1.9

Katikou P., Georgantalis D., Sinouris N., Petsi A., Fotaras T. 2009. First report on toxicity assessment of the Lessepsian migrant pufferfish Lagocephalus sceleratus (Gmelin, 1789) from European waters (Aegean Sea, Greece). Toxicon 54 (1): 50-55. DOI: $10.1016 /$ j.toxicon.2009.03.012

Katsanevakis S., Tsiamis K., Ioannou G., Michailidis N., Zenetos A. 2009. Inventory of alien marine species of Cyprus. Mediterranean Marine Science 10 (2): 109-133. DOI: $10.12681 / \mathrm{mms} .113$

Koukouras A., Kitsos M.-S., Tzomos Th., Tselepides A. 2010. Evolution of the entrance rate and of the spatio-tem- 
poral distribution of Lessepsian Crustacea Decapoda in the Mediterranean Sea. Crustaceana 83 (12): 1409-1430.

DOI: $10.1163 / 001121610 X 539498$

Milazzo M., Azzurro E., Badalamenti F. 2012. On the occurrence of the silverstripe blaasop Lagocephalus sceleratus (Gmelin, 1789) along the Libyan coast. Bioinvasions Records 1 (2): 125-127.

DOI: $10.3391 /$ bir.2012.1.2.08

Mouneimne N. 1977. Liste des poisons de la côte du Liban (Méditerranée orientale). Cybium 1 (1): 37-66.

Nader M.R., Indary S., Boustany L. 2012. The puffer fish Lagocephalus sceleratus (Gmelin, 1789) in the Eastern Mediterranean. FAO and EastMed Technical Document No. 10. GCP/INT/041/EC-GRE-ITA/TD-10. Athens, Greece.

Otero M., Cebrian E., Francour P., Galil B., Savini D. 2013. Monitoring marine invasive species in Mediterranean marine protected areas (MPAs): A strategy and practical guide for managers. IUCN, Malaga, Spain.

Peristeraki P., Lazarakis G., Skarvelis C., Georgiadis M., Tserpes G. 2006. Additional records on the occurrence of alien fish species in the eastern Mediterranean Sea. Mediterranean Marine Science 7 (2): 61-66. DOI: $10.12681 / \mathrm{mms} .170$

Shakman E., Kinzelbach R. 2007. Commercial fishery and fish species composition in coastal waters of Libya. Rostocker Meeresbiologische Beiträge 18: 63-78.

Smith M.M., Heemstra P.C. 1986. Smith's Sea Fishes. Smith Institute of Ichthyology Press, Grahamstown, Republic of South Africa.

Streftaris N. Zenetos A. 2006. Alien marine species in the Mediterranean - the 100 'worst invasives' and their impact. Mediterranean Marine Science 7 (1): 87-118.

DOI: $10.12681 / \mathrm{mms} .180$

Sulić Šprem J., Dobroslavić T., Kožul V., Kuzman A., Dulčić J. 2014. First record of Lagocephalus sceleratus in the Adriatic Sea (Croatian coast), a Lessepsian migrant. Cybium 38 (2): 147-148.

Torcu Koç H., Erdoğan Z., Üstün F. 2011. Occurrence of the Lessepsian migrant, Lagocephalus sceleratus (Gmelin
1789) (Osteichtyes: Tetraodontidae), in İskenderun Bay (north-eastern Mediterranean, Turkey). Journal of Applied Ichthyology 27 (1): 148-149.

DOI: $10.1111 /$ j.1439-0426.2010.01628.x

Turan C. (ed.) 2007. Türkiye Kemikli Deniz Balıkları Atlası ve Sistematiği. [Atlas and systematic of marine bony fishes of Turkey.] Adana Nobel, Adana Turkey. [In Turkish.]

Türker-Çakır D., Yarmaz A., Balaban C. 2009. A new record of Lagocephalus sceleratus (Gmelin 1789) confirming a further range extension into the northern Aegean Sea. Journal of Applied Ichthyology 25 (5): 606-607. DOI: $10.1111 / j .1439-0426.2009 .01276 . x$

Vargas-Yáñez M., Salat J., Luz Fernández de Puelles M., López-Jurado J.L., Pascual J., Ramírez T., Cortés D., Franco I. 2005. Trends and time variability in the northern continental shelf of the western Mediterranean. Journal of Geophysical Research 110: C10019.

DOI: $10.1029 / 2004 J C 002799$

Yaglioglu D., Turan C., Erguden D., Gurlek M. 2011. Range expansion of silverstripe, Lagocephalus sceleratus (Gmelin, 1789), to the northeastern Mediterranean Sea. Biharean Biologist 5 (2): 159-161.

Zaki A.M. 2004. Tetrodoxin poisoning with eating puffer fish in Suez City (Egypt). P. 72. In: International Conference on NaturalToxins, 18-19 December 2004, October 6 University, 6th of October City, Egypt.

Zenetos A., Çinar M.E., Pancucci-Papadopoulou M.A., Harmelin J.G., Furnari G., Andaloro F., Bellou N., Streftaris N., Zibrowius H. 2005. An annotated list of marine alien species in the Mediterranean with records of the worst invasive species. Mediterranean Marine Science 6 (2): 63-118. DOI: $10.12681 / \mathrm{mms} .186$

Received: 1 September 2014 Accepted: 18 February 2015 Published electronically: 31 March 2015 